\title{
HIF-1 and human disease: one highly involved factor
}

\author{
Gregg L. Semenza ${ }^{1}$ \\ Institute of Genetic Medicine, Departments of Pediatrics and Medicine, The Johns Hopkins University School of Medicine, \\ Baltimore, Maryland 21287-3914 USA
}

Oxygen homeostasis represents an important organizing principle for human development and physiology. The essential requirement for oxidative phosphorylation to generate ATP is balanced by the risk of oxidative damage to cellular lipids, nucleic acids, and proteins. As a result, cellular and systemic $\mathrm{O}_{2}$ concentrations are tightly regulated via short- and long-acting response pathways that affect the activity and expression of a multitude of cellular proteins (for review, see Semenza 1999a). This delicate balance is disrupted in heart disease, cancer, cerebrovascular disease, and chronic obstructive pulmonary disease, which represent the most common causes of mortality and account for two-thirds of all deaths in the U.S. (Greenlee 2000). Appreciation of the fundamental importance of oxygen homeostasis for development, physiology, and disease pathophysiology is growing but still incomplete. Knowledge acquisition is presently exponential when one includes areas, such as the role of angiogenesis in ischemic or neoplastic disease, in which investigators are studying oxygen homeostasis even though they may not interpret their studies within this broad physiological context.

Vascular endothelial growth factor (VEGF) plays an essential role in angiogenesis (for review, see Ferrara and Davis-Smyth 1997; Ferrara 1999). The regulation of VEGF expression illustrates how reduced $\mathrm{O}_{2}$ availability (hypoxia) can elicit physiological responses via multiple molecular mechanisms. VEGF expression is induced when most cell types are subjected to hypoxia, thus providing a mechanism by which tissue perfusion can be optimized to demand. Steady state levels of VEGF mRNA increase in hypoxic cells as a result of increased production (transcriptional activation) and decreased destruction (mRNA stabilization). Whereas overall protein synthesis is inhibited in response to hypoxia, VEGF mRNA is efficiently translated into protein by use of an internal ribosome entry site (Stein et al. 1998). Finally, expression of the VEGF receptor FLT-1 is also induced when endothelial cells are exposed to hypoxia (Gerber et al. 1997).

The essential first step in this process, transcriptional activation, is mediated by the binding of hypoxia-induc-

${ }^{1}$ E-MAIL gsemenza@jhmi.edu; FAX (410) 955-0484. ible factor 1 (HIF-1) to a cis-acting hypoxia-response element located $1 \mathrm{~kb} 5^{\prime}$ to the transcriptional start site of the human VEGF gene (Forsythe et al. 1996). HIF-1 is a basic helix-loop-helix PAS protein consisting of HIF-1 $\alpha$ and HIF-1 $\beta$ subunits (Wang and Semenza 1995; Wang et al. 1995). HIF-1 $\alpha$ expression and HIF-1 transcriptional activity are precisely regulated by cellular $\mathrm{O}_{2}$ concentration (for review, see Semenza 1999b, 2000a; Wenger 2000). The molecular mechanisms of sensing and signal transduction by which changes in $\mathrm{O}_{2}$ concentration result in changes in HIF-1 activity are poorly understood, but recent data suggest that the $\mathrm{O}_{2}$ signal is converted to a redox signal (Chandel et al. 2000; Haddad et al. 2000) that may trigger a kinase cascade and/or regulate HIF-1 directly (for review, see Semenza 1999a,b; Chandel and Schumacker 2000).

The regulation of HIF-1 activity occurs at multiple levels. Whereas HIF-1 $\alpha$ mRNA is constitutively expressed in tissue culture cells, it is markedly induced by hypoxia or ischemia in vivo (Yu et al. 1998; Bergeron et al. 1999). HIF- $1 \alpha$ protein expression is negatively regulated in nonhypoxic cells by ubiquitination and proteasomal degradation (Salceda and Caro 1997; Huang et al. 1998; Kallio et al. 1999). Under hypoxic conditions, HIF-1 $\alpha$ protein levels increase dramatically and the fraction that is ubiquitinated decreases (Sutter et al. 2000). Nuclear localization of HIF-1 $\alpha$ may also be induced by hypoxia (Kallio et al. 1998). The carboxy-terminal half of HIF- $1 \alpha$ contains two transactivation domains that are also negatively regulated under nonhypoxic conditions (Jiang et al. 1997b; Pugh et al. 1997). The interaction of these domains with the coactivators CBP, p300, SRC-1, and TIF2 is regulated by the cellular $\mathrm{O}_{2}$ concentration and redox state (Kallio et al. 1998; Ema et al. 1999; Carrero et al. 2000). Finally, species-specific alternative splicing of human and mouse HIF-1 $\alpha$ RNA has also been reported (Wenger et al. 1997; Iyer et al. 1998b; Gothie et al. 2000). Hypoxia results in the rapid accumulation of HIF-1 $\alpha$ in the nucleus (Wang et al. 1995) where it dimerizes with HIF- $1 \beta$ and binds to the core DNA sequence 5 '-RCGTG3' (Semenza 2000a), leading to the transcriptional activation of $V E G F$ and several dozen other known target genes (Table 1). HIF- $1 \alpha$ and HIF-1 $\beta$ expression are required for embryonic survival in mice (Kozak et al. 1997; Maltepe et al. 1997; Iyer et al. 1998a; Ryan et al. 1998; 
Table 1. Direct HIF-1 target genes ${ }^{a}$

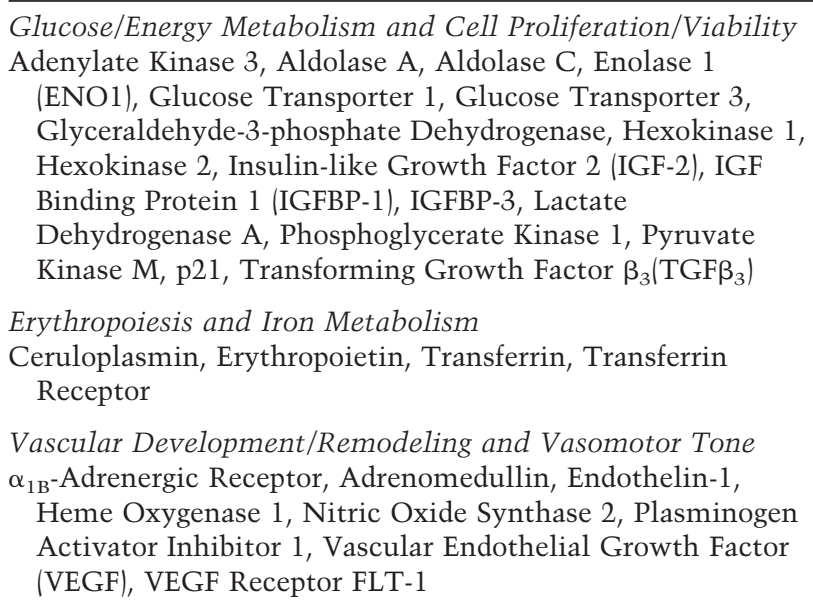

Vascular Development/Remodeling and Vasomotor Tone $\alpha_{1 \mathrm{~B}}$-Adrenergic Receptor, Adrenomedullin, Endothelin-1, Heme Oxygenase 1, Nitric Oxide Synthase 2, Plasminogen Activator Inhibitor 1, Vascular Endothelial Growth Factor (VEGF), VEGF Receptor FLT-1

Other

p35 $5^{\text {srg }}$

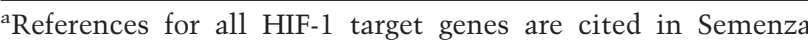
2000b, except for TGF $\beta_{3}$ (Caniggia et al. 2000) and ceruloplasmin (Mukhopadhyay et al. 2000).

Kotch et al. 1999). Proteins that are structurally related to HIF- $1 \alpha$ (HIF-2 $\alpha, \mathrm{HIF}-3 \alpha$ ) and HIF-1 $\beta$ (ARNT2, ARNT3) have been identified (for review, see Semenza 2000a) but their biological functions have not been established except for the finding that mice lacking HIF-2 $\alpha$ (also known as EPAS1) die at midgestation because of catecholamine deficiency and heart failure (Tian et al. 1998). This review will focus on recent publications that have demonstrated involvement of HIF-1 in human disease pathophysiology.

\section{Ischemic cardiovascular disorders}

\section{Myocardial ischemia}

Atherosclerosis leads to arterial stenosis, impaired perfusion of the downstream vascular bed, and ischemia. When oxygen and glucose deprivation irreversibly affect myocardial viability, the end result is an infarction (heart attack). Hypoxia/ischemia has dramatic stimulatory effects on vascularization of coronary and peripheral vascular beds in fetal and juvenile animals whereas angiogenesis is markedly inhibited in aged animals because of impairment of VEGF production and endothelial cell responses to VEGF (Martin et al. 1998; Rivard et al. 1999). The impairment of VEGF production can be attributed to decreased HIF-1 activity in response to hypoxia (Frenkel-Denkberg et al. 1999; Rivard et al. 2000). Among middle-aged adults there is also variation in the extent to which ischemia induces the development of collateral blood vessels that allow perfusion of myocardium downstream of coronary artery stenosis and that influence the incidence and severity of myocardial infarction (Habib et al. 1991; Sabia et al. 1992). Myocardial ischemia induces VEGF expression (Banai et al. 1994) and the extent to which VEGF is induced in cultured leukocytes exposed to hypoxia ex vivo is correlated with the degree of coronary collateralization induced by myocardial ischemia in vivo (Schultz et al. 1999). HIF-1 $\alpha$ mRNA and protein expression are induced and precede VEGF expression during acute ischemia and early infarction in the human heart (Lee et al. 2000). Thus, it is possible that variation in ischemia-induced HIF-1 activity may underlie the observed variation in VEGF expression and represent an important risk factor for myocardial infarction. In addition, therapeutic strategies designed to increase HIF- $1 \alpha$ expression may promote angiogenesis within ischemic myocardium. PR39, a macrophage-derived peptide, has been shown to induce myocardial angiogenesis via inhibition of HIF-1 $\alpha$ degradation (Li et al. 2000).

Ischemic preconditioning is an experimental phenomenon in which subjecting an animal to a sublethal ischemic challenge results in protection against a subsequent lethal challenge. There is an immediate but shortlived phase of protection within the first $2-3 \mathrm{hr}$ that is followed by a delayed but sustained late phase of protection 12-24 hr later that requires new protein synthesis (Rizvi et al. 1999, and references therein). The late phase of ischemic preconditioning is lost in knockout mice that lack expression of the Nos2 gene encoding inducible nitric oxide (NO) synthase (Guo et al. 1999). Induction of Nos2 expression in hypoxic cardiac myocytes and vascular endothelial cells may be mediated by HIF-1 (Palmer et al. 1998; Jung et al. 2000). Furthermore, NO has been shown to induce HIF-1 $\alpha$ expression under nonhypoxic conditions (Kimura et al. 2000). NO has been proposed to be both a trigger and a mediator of delayed preconditioning (Bolli et al. 1997). Thus, NO production in response to the preconditioning stimulus may induce HIF-1-mediated NOS2 expression that is protective against a subsequent lethal ischemic challenge. As in the case of ischemia-induced angiogenesis, once the molecular mechanisms of this process are more completely understood it may be possible to identify pharmacologic inducers that would have great therapeutic utility.

\section{Cerebral ischemia}

When adult rats are subjected to permanent middle cerebral artery occlusion, HIF- $1 \alpha$ mRNA is induced in the penumbra or viable tissue surrounding the infarction (Bergeron et al. 1999). The induction of HIF-1 $\alpha$ mRNA is temporally and spatially correlated with the expression of mRNAs encoding glucose transporter 1 and the glycolytic enzymes aldolase A, lactate dehydrogenase A, phosphofructokinase $\mathrm{L}$, and pyruvate kinase $\mathrm{M}$, which are all known HIF-1 target genes (Iyer et al. 1998a; Table 1). These data suggest that induction of glycolytic metabolism may promote the survival of neurons within the penumbra. Colocalization of HIF- $1 \alpha$ and VEGF expression has also been demonstrated in the penumbra and is associated with neovascularization (Marti et al. 2000). In contrast, studies of primary cortical cultures from newborn mouse brains revealed that inhibition of 
HIF-1 activity by overexpression of a dominant negative form of HIF-1 $\alpha$ (Jiang et al. 1996) is associated with reduced cell death in response to oxygen and glucose deprivation (Halterman et al. 1999). Studies of HIF-1 $\alpha$-null embryonic stem cells also implicated HIF- $1 \alpha$ in mediating apoptosis in response to oxygen and glucose deprivation (Carmeliet et al. 1998). These results are consistent with a model in which hypoxia-induced HIF-1 $\alpha$ associates with and prevents the degradation of p53 protein (An et al. 1998), which then induces apoptosis of cortical neurons (Banasiak and Haddad 1998).

When newborn rats are subjected to permanent left common carotid artery occlusion and exposed to $8 \% \mathrm{O}_{2}$, cerebral infarction occurs in the hemisphere ipsilateral to the occlusion. Rats exposed to $8 \% \mathrm{O}_{2}$ for $3 \mathrm{hr}$ and then subjected to carotid occlusion and hypoxia $24 \mathrm{hr}$ later are protected against cerebral infarction (Gidday et al. 1994). As in the case of myocardial preconditioning (Bolli et al. 1997), cerebral preconditioning is blocked by NOS inhibitors (Gidday et al. 1999). Significant protection can also by achieved by injecting the rats with cobalt chloride or desferrioxamine (Bergeron et al. 2000), which are known inducers of HIF-1 activity (Wang and Semenza 1993). Exposure of rats to hypoxia alone induces HIF-1 $\alpha$ protein expression throughout the brain, whereas combined carotid occlusion and hypoxia result in decreased HIF- $1 \alpha$ expression in the ipsilateral cortex and a striking induction within the microvasculature of the ischemic brain (Bergeron et al. 2000). The physiological significance of this dramatic alteration in HIF-1 $\alpha$ expression remains to be determined. In contrast to the data from in vivo studies suggesting that HIF- $1 \alpha$ expression may contribute to hypoxic preconditioning, studies of cultured neurons suggest that hypoxic preconditioning ex vivo leads to decreased HIF-1 $\alpha$ expression in response to oxygen-glucose deprivation $48 \mathrm{hr}$ later (Ruscher et al. 1998). Thus, it will be important to definitively establish, for example, by analysis of partially HIF- $1 \alpha$-deficient mice (see below), whether the net effect of HIF-1 $\alpha$ in vivo is protective or pathogenic and then to determine which cell types (glia, inflammatory cells, neurons) contribute to this effect.

\section{Retinal ischemia}

In diabetes, occlusion of retinal vessels leads to ischemia-induced neovascularization, which is a major cause of blindness. Clinical and laboratory studies have demonstrated a critical role of VEGF in this process (for review, see Ferrara 1999). In a mouse model of ischemic retinopathy, exposure of neonates to hyperoxia for five days results in vascular regression and retinal ischemia when the mice are returned to room air (Pierce et al. 1995), conditions similar to those that result in the retinopathy of prematurity. HIF- $1 \alpha$ expression is induced during normal retinal development, is downregulated by hyperoxia, and upregulated on return to normoxic conditions, a pattern that is temporally and spatially correlated with VEGF expression (Ozaki et al. 1999).

\section{Pulmonary hypertension}

In some patients with chronic obstructive lung disease, alveolar hypoxia leads to the development of pulmonary hypertension. In this disorder, hypoxia-induced pulmonary arteriolar remodeling results in reduced lumen diameter and increased resistance to blood flow, leading to progressive right heart failure and, ultimately, patient death. Mice exposed to $10 \% \mathrm{O}_{2}$ for three weeks develop right ventricular hypertrophy as a result of increased right ventricular pressure, which is in turn secondary to medial wall hypertrophy within small pulmonary arterioles. This hypoxia-induced vascular remodeling is markedly impaired in mice that are heterozygous for a loss-of-function allele at the Hif1a locus and therefore partially HIF-1 $\alpha$ deficient (Yu et al.1999). These results suggest that local inhibition of HIF-1 activity in the lung might represent a therapeutic strategy for treating or preventing pulmonary hypertension in at risk individuals.

\section{Pregnancy disorders: preeclampsia and intrauterine growth retardation}

Preeclampsia is a disorder of unknown etiology that affects $5 \%$ of all pregnancies and is a leading cause of fetal and maternal morbidity and mortality (for review, see Norwitz and Repke 2000; Roberts 2000). A central defect in preeclampsia appears to be the failure of trophoblasts to adequately invade the myometrium and induce remodeling of uterine spiral arteries during early placentation, which results in decreased uteroplacental perfusion (for review, see Aplin 2000). For most of the first trimester, the human fetus and placenta develop under hypoxic conditions but, at 10-12 weeks, the intervillous space opens and the placenta and fetus are exposed to maternal blood. It is at this stage that trophoblast cells actively invade the maternal decidua, and the developmental switch of trophoblasts from a proliferative to an invasive phenotype is controlled by the cellular $\mathrm{O}_{2}$ concentration (Genbacev et al. 1996, 1997). The proliferative, noninvasive trophoblast phenotype appears to be maintained by hypoxia-induced, HIF-1-mediated expression of $\mathrm{TGF}_{3}$ because treatment of human villous explants with antisense oligonucleotides against HIF- $1 \alpha$ or TGF $\beta_{3}$ induces invasion under hypoxic conditions (Caniggia et al. 2000). Inhibition of $\mathrm{TGF}_{3}$ also induces trophoblast invasion in explants from preeclamptic pregnancies (Caniggia et al. 1999), suggesting that defective downregulation of HIF$1 \alpha$ and/or TGF $\beta_{3}$ may play a major role in the pathogenesis of preeclampsia.

Another leading cause of fetal and neonatal morbidity and mortality is intrauterine growth retardation (IUGR). Decreased placental perfusion, resulting in placental and fetal hypoxia, is believed to be a major cause of IUGR. Fetal and maternal insulin-like growth factors (IGFs) play an important role in regulating fetal growth. IGFbinding protein 1 (IGFBP-1) is a negative regulator of IGF activity. IGFBP-1 expression, which is induced by hypoxia via a HIF-1 binding site in the gene promoter, is greatly increased in the cord blood of newborn children with IUGR (Tazuke et al. 1998). 


\section{Cancer}

Hypoxia is an important selective force in the clonal evolution of tumors (Graeber et al. 1996) and HIF-1 $\alpha$ is overexpressed in common human cancers (Zhong et al. 1999; Zagzag et al. 2000). The involvement of HIF-1 in tumor progression has been reviewed in detail (Semenza 2000b) but the major physiologic and genetic mechanisms leading to HIF-1 $\alpha$ overexpression are summarized below.

\section{Angiogenesis and hypoxia}

Until primary tumors establish a blood supply, the limited diffusion of $\mathrm{O}_{2}$ from nearby host vessels limits their growth to no more than a few cubic millimeters because cell division is balanced by cell death. Increased expression of VEGF is essential for the establishment of angiogenesis in most solid tumors. Experimental data (for review, see Semenza 2000b) suggest the following model: Increased VEGF expression is required to initiate and sustain tumor angiogenesis. Increased VEGF levels result from the synergistic effects of tumor hypoxia and tumor-specific genetic alterations (mutations) involving oncogenes and tumor suppressor genes. Increased VEGF expression results in the formation of dysfunctional vasculature that cannot adequately perfuse the entire tumor. Cellular adaptation to hypoxia is therefore a requirement of tumor progression independent of angiogenesis. As a result, most solid tumors have the seemingly paradoxical characteristic that poor clinical outcome is significantly correlated with both vascular density and tumor hypoxia.

In human gliomas, there is a significant association between tumor grade, vascularization, and HIF- $1 \alpha$ overexpression (Zagzag et al. 2000). The highest grade glioma is glioblastoma multiforme (GBM), which is associated with a mean patient survival time of less than one year, regardless of treatment. In this condition, the rapidly proliferating tumor cells outstrip their blood supply resulting in extensive necrosis. The viable tumor cells surrounding necrotic regions express high levels of HIF-1 $\alpha$ protein (Zhong et al. 1999; Zagzag et al. 2000) and VEGF mRNA (Plate et al. 1992; Shweiki et al. 1992). This pattern of expression suggests that the tumor cells are responding to hypoxia by HIF-1-mediated VEGF expression as demonstrated previously in cultured cells and mouse xenografts (Forsythe et al. 1996; Maxwell et al. 1997; Carmeliet et al. 1998; Iyer et al. 1998a; Ryan et al. 1998). GBMs have multiple mutations that inactivate tumor suppressor genes, including $p 14 A R F, p 16 C D K N 2 A$, TP53, and PTEN (Ishii et al. 1999), or activate oncogenes, including CDK4, EGFR, and MDM2 (Holland et al. 1998). Remarkably, recent studies have established that mutations in oncogenes and tumor suppressor genes which had previously been shown to increase VEGF expression do so by induction of HIF-1, as described below.

\section{Tumor suppressor genes}

Hemangioblastoma is a brain tumor that differs from GBM by a lack of necrosis. This tumor is so well vascu- larized that, as its name implies, it was originally believed to arise from the progenitor cells for blood and vascular endothelial cells. Instead, hemangioblastomas produce extraordinarily high levels of VEGF that are responsible for inducing extensive vascularization. Remarkably, all hemangioblastomas analyzed overexpress HIF-1 $\alpha$ (Zagzag et al. 2000). Hypoxia is unlikely to be a stimulus for HIF-1 $\alpha$ expression in these cells. The key genetic lesion in hemangioblastoma and in clear cell renal carcinoma, another extensively vascularized tumor type, is functional inactivation of the von Hippel-Lindau (VHL) tumor suppressor (Gnarra et al. 1994; Herman et al. 1994; Kanno et al. 1994; Shuin et al. 1994). In renal carcinoma cell lines, VHL loss-of-function results in constitutive expression of HIF-1 $\alpha$ under nonhypoxic conditions (Maxwell et al. 1999). VHL is associated with ubiquitin-protein ligase activity (Lisztwan et al. 1999) and loss of VHL function in renal carcinoma cells results in defective ubiquitination of HIF- $1 \alpha$ under nonhypoxic conditions (Cockman et al. 2000).

p53 loss-of-function also leads to an increase in HIF- $1 \alpha$ and VEGF expression that, although less dramatic than that associated with VHL loss-of-function, affects many more tumors, as loss of p53 activity occurs via one or more molecular mechanisms in the majority of human cancers (for review, see Giaccia and Kastan 1998). Remarkably, p53 also acts to target HIF- $1 \alpha$ for ubiquitination but, in contrast to VHL, loss of p53 activity primarily leads to augmented hypoxia-induced HIF-1 $\alpha$ and VEGF expression (Ravi et al. 2000). This is possible because there is considerable ubiquitination of HIF- $1 \alpha$ even under hypoxic conditions (Sutter et al. 2000). HIF$1 \alpha$ and p53 directly interact, leading to the recruitment of the ubiquitin-protein ligase MDM2, which binds to p53 (Ravi et al. 2000). HIF-1 $\alpha$ expression increases the stability of p53 (An et al. 1998) whereas p53 decreases the stability of HIF-1 $\alpha$ in an MDM2-dependent manner (Ravi et al. 2000), suggesting that within the trimolecular complex HIF-1 $\alpha$ is a preferential target of MDM2. HIF- $1 \alpha$-mediated stabilization of p53 may also play a role in hypoxia-mediated apoptosis leading to selection for loss of p53 function in tumor cells (Graeber et al. 1996).

\section{Oncogenes}

Dysregulation of signal transduction pathways regulating cell proliferation and viability is a hallmark of cancer. This can occur through gain-of-function mutations in genes encoding receptor tyrosine kinases such as EGFR, HER2 ${ }^{\text {neu }}$, or IGF-1R, and nonreceptor tyrosine kinases, such as c-SRC. The prototype oncogene, v-SRC, induces the expression of HIF-1 $\alpha$ protein, HIF-1 DNAbinding and transcriptional activity, and mRNAs encoding VEGF and ENO1 (Jiang et al. 1997a). The biological effects of oncogenic tyrosine kinases occur via activation of the RAS, phosphatidylinositol-3-kinase (PI3K)/AKT (protein kinase B), and/or RAF/MEK/ERK (MAP kinase) pathways. In human prostate cancer cells, HIF-1 $\alpha$ and VEGF overexpression are mediated via the PI3K/AKT pathway via the downstream effector kinase FKBP/rapa- 
mycin-associated protein IFRAP; also known as mammalian target of rapamycin (mTOR)[ (Zhong et al. 2000). Exposure of cells to LY294002 or rapamycin, inhibitors of PI3K and FRAP, respectively, completely blocks HIF$1 \alpha$ expression in nonhypoxic cells. In human prostate cancer and glioma cell lines, HIF-1-dependent transcription can be induced by a constitutively active form of AKT or a dominant-negative form of the phosphatase PTEN, which functions as a tumor suppressor by negatively regulating the PI3K/AKT pathway (Zhong et al. 2000; Zundel et al. 2000). PTEN loss of function is correlated with angiogenesis and advanced tumor stage in human prostate cancer (Giri and Ittmann 1999; McMenamin et al. 1999). Overexpression of PTEN in glioma cells dramatically reduces the accumulation of HIF-1 $\alpha$ (Zundel et al. 2000), suggesting that the PI3K/ AKT pathway may also regulate the ubiquitination of HIF-1 $\alpha$.

Oncogenic RAS mutations are also very common in human cancer and can lead to VEGF expression via either the PI3K or MAPK pathway, depending upon the cell type (Rak et al. 2000). The induction of VEGF promoter activity in H-RAS-transformed NIH 3T3 cells is dependent on PI3K (but not FRAP) activity and the presence of an intact HIF-1-binding site (Mazure et al. 1997). In CCL-39 fibroblasts, expression of RAF-1 results in phosphorylation of HIF- $1 \alpha$ by p 42 and p44 ERK, which is associated with increased HIF-1 transcriptional activity but no increase in HIF-1 $\alpha$ protein expression (Richard et al. 1999), suggesting an effect on transactivation domain function, but the site of phosphorylation has not been reported. HIF-1 $\alpha$ may also be phosphorylated by ERK in HMEC-1 endothelial cells under hypoxic conditions (Minet et al. 2000). Exposure of mouse embryonic fibroblasts to the organomercurial compound mersalyl induces the expression of HIF-1 $\alpha$ protein, HIF-1 DNA-binding and transcriptional activity, and mRNAs encoding VEGF and ENO1, an effect that is dependent on the presence of IGF-1R and MEK activity (Agani and Semenza 1998). These studies suggest that the MAP kinase pathway can regulate HIF- $1 \alpha$ protein stabilization or transactivation in a cell-type or stimulus-specific manner.

\section{Effects of increased HIF-1 activity on tumor biology}

Taken together, recent data indicate that HIF-1 activity is increased by both physiologic and epigenetic mechanisms in human cancer. Analysis of isogenic cell lines in nude mouse xenograft assays indicate that loss of HIF-1 activity results in increased tumor latency and decreased vascular density (Jiang et al. 1997a; Maxwell et al. 1997; Carmeliet et al. 1998; Ryan et al. 1998), whereas overexpression of HIF-1 $\alpha$ results in decreased tumor latency and increased vascular density, volume, and permeability (Ravi et al. 2000). Known HIF-1 target genes provide a molecular basis by which HIF-1 overexpression may promote key aspects of tumor progression (Table 1): Glucose transporters and glycolytic enzymes promote metabolic adaptation to hypoxia; NOS2 and VEGF promote angiogenesis; IGF-2 promotes cell survival and prolifera-

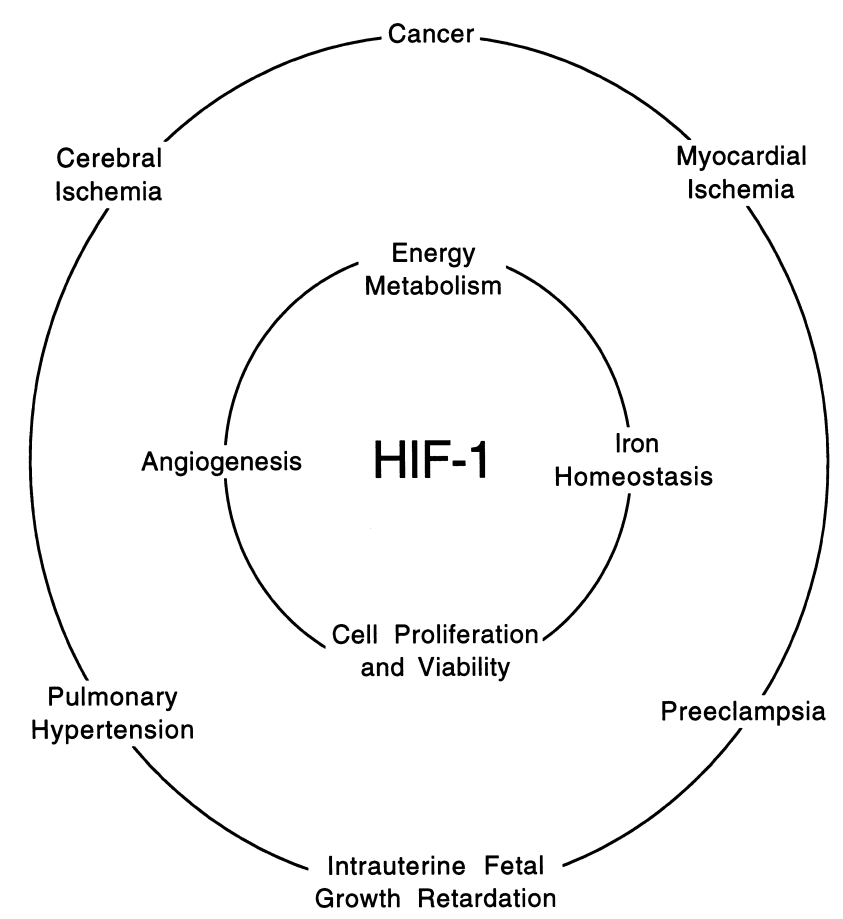

Figure 1. Involvement of HIF-1 in key physiological and pathophysiological processes. HIF-1 participates in essential developmental and physiological processes (inner circle) via transactivation of target genes (see Table 1). HIF-1 transactivation of target genes also contributes to either protective or pathologic responses in several major disease states (outer circle) as described in the text.

tion. Novel therapeutic strategies designed to exploit the decreased $\mathrm{O}_{2}$ concentration or increased HIF-1 expression within tumors are presently being evaluated (Dachs et al. 1997; Brown 2000; Shibata et al. 2000).

\section{Conclusion}

Data regarding the involvement of HIF-1 in developmental, physiological, and pathophysiological processes (Fig. 1) are presently accumulating at an exponential rate. Potential clinical applications of this knowledge will be dependent on continued scientific progress in three general areas: delineation of the complex cell-type- and stimulus-specific mechanisms by which HIF-1 activity is regulated; characterization of the target genes and biological processes that are regulated by HIF-1 within a given cell type and (patho)physiological state; and development of technology for efficient cell-type-specific targeting of DNA- and small-molecule-based therapeutics.

\section{Acknowledgments}

Work in the author's laboratory is supported by grants from the American Heart Association Mid-Atlantic Affiliate, Children's Brain Tumor Foundation, and the National Institutes of Health (R01-DK39869, R01-HL55338). 


\section{References}

Agani, F. and Semenza, G.L. 1998. Mersalyl is a novel inducer of vascular endothelial growth factor gene expression and hypoxia-inducible factor 1 activity. Mol. Pharmacol. 54: 749754.

An, W.G., Kanekal, M., Simon, M.C., Maltepe, E., Blagosklonny, M.V., and Neckers, L.M. 1998. Stabilization of wildtype p53 by hypoxia-inducible factor $1 \alpha$. Nature 392: 405408.

Aplin, J.D. 2000. Hypoxia and human placental development. J. Clin. Invest. 105: 559-560.

Banai, S., Shweiki, D., Pinson, A., Chandra, M., Lazarovici, G., and Keshet, E. 1994. Upregulation of vascular endothelial growth factor expression induced by myocardial ischemia: Implication for coronary angiogenesis. Cardiovasc. Res. 28: 1176-1179.

Banasiak, K.J. and Haddad, G.G. 1998. Hypoxia-induced apoptosis: Effect of hypoxic severity and role of p53 in neuronal cell death. Brain Res. 797: 295-304.

Bergeron, M., Yu, A.Y., Solway, K.E., Semenza, G.L., and Sharp, F.R. 1999. Induction of hypoxia-inducible factor-1 (HIF-1) and its target genes following focal ischemia in rat brain. Eur. J. Neurosci. 11: 4159-4170.

Bergeron, M., Gidday, J.M., Yu, A.Y., Semenza, G.L., Ferriero, D.M., and Sharp, F.R. 2000. Role of hypoxia-inducible factor 1 in hypoxia-induced tolerance in neonatal rat brain. Ann. Neurol. (in press).

Bolli, R., Manchikalapudi, S., Tang, X.-L., Takano, H., Qiu, Y., Guo, Y., Zhang, Q., and Jadoon, A.K. 1997. The protective effect of late preconditioning against myocardial stunning in conscious rabbits is mediated by nitric oxide synthase: Evidence that nitric oxide acts both as a trigger and as a mediator of the late phase of ischemic preconditioning. Circ. Res. 81: 1094-1107.

Brown, J.M. 2000. Exploiting the hypoxic cancer cell: Mechanisms and therapeutic strategies. Mol. Med. Today 6: 157162.

Caniggia, I., Grisaru-Gravnosky, S., Kuliszewski, M., Post, M., and Lye, S.J. 1999. Inhibition of $\mathrm{TGF}_{3}$ restores the invasive capacity of extravillous trophoblasts in pre-eclamptic pregnancies. J. Clin. Invest. 103: 1641-1650.

Caniggia, I., Mostachfi, H., Winter, J., Gassmann, M., Lye, S.J., Kuliszewski, M., and Post, M. 2000. Hypoxia-inducible factor-1 mediates the biological effects of oxygen on human trophoblast differentiation through $\mathrm{TGF}_{3}$. I. Clin. Invest. 105: 577-587.

Carmeliet, P., Dor, Y., Herbert, J.-M., Fukumura, D., Brusselmans, K., Dewerchin, M., Neeman, M., Bono, F., Abramovitch, R., Maxwell, P., et al. 1998. Role of HIF-1 $\alpha$ in hypoxiamediated apoptosis, cell proliferation, and tumour angiogenesis. Nature 394: 485-490.

Carrero, P., Okamato, K., Coumailleau, P., O’Brien, S., Tanaka, H., and Poellinger, L. 2000. Redox-regulated recruitment of the transcriptional coactivators CREB-binding protein and SRC-1 to hypoxia-inducible factor $1 \alpha$. Mol. Cell. Biol. 20: 402-415.

Chandel, N.S. and Schumacker, P.T. 2000. Cellular oxygen sensing by mitochondria: Old questions, new insight. $I$. Appl. Physiol. 88: 1880-1889.

Chandel, N.S., McClintock, D.S., Feliciano, C.E., Wood, T.M., Melendez, J.A., Rodriguez, A.M., and Schumacker, P.T. 2000. Reactive oxygen species generated at mitochondrial Complex III stabilize HIF-1 $\alpha$ during hypoxia: A mechanism of $\mathrm{O}_{2}$ sensing. J. Biol. Chem. (in press).

Cockman, M.E., Masson, N., Mole, D.R., Jaakkola, P., Chang,
G.W., Clifford, S.C., Maher, E.R., Pugh, C.W., Ratcliffe, P.J., and Maxwell, P.H. 2000. Hypoxia inducible factor- $\alpha$ binding and ubiquitylation by the von Hippel-Lindau tumor suppressor protein. J. Biol. Chem. (in press).

Dachs, G.U., Patterson, A.V., Firth, J.D., Ratcliffe, P.J., Townsend, K.M., Stratford, I.J., and Harris, A.L. 1997. Targeting gene expression to hypoxic tumor cells. Nat. Med. 3: $515-520$.

Ema, M., Hirota, K., Mimura, J., Abe, H., Yodoi, J., Sogawa, K., Poellinger, L., and Fujii-Kuriyama, Y. 1999. Molecular mechanisms of transcription activation by HLF and HIF $1 \alpha$ in response to hypoxia: Their stabilization and redox signalinduced interaction with $\mathrm{CBP} / \mathrm{p} 300 . \quad E M B O \quad J$. 18: $1905-1914$.

Ferrara, N. 1999. Molecular and biological properties of vascular endothelial growth factor. J. Mol. Med. 77: 527-543.

Ferrara, N. and Davis-Smyth, T. 1997. The biology of vascular endothelial growth factor. Endocr. Rev. 18: 4-25.

Forsythe, J.A., Jiang, B.-H., Iyer, N.V., Agani, F., Leung, S.W., Koos, R.D., and Semenza, G.L. 1996. Activation of vascular endothelial growth factor gene transcription by hypoxia-inducible factor 1. Mol. Cell. Biol. 16: 4604-4613.

Frenkel-Denkberg, G., Gershon, D., and Levy, A.P. 1999. The function of hypoxia-inducible factor 1 (HIF-1) is impaired in senescent mice. FEBS Lett. 462: 341-344.

Genbacev, O., Joslin, R., Damsky, C.H., Polliotti, B.M., and Fisher, S.J. 1996. Hypoxia alters early gestation human cytotrophoblast differentiation/invasion in vitro and models the placental defects that occur in preeclampsia. J. Clin. Invest. 97: 540-550.

Genbacev, O., Zhou, Y., Ludlow, J.W., and Fisher, S.J. 1997. Regulation of human placental development by oxygen tension. Science 277: 1669-1672.

Gerber, H.-P., Condorelli, F., Park, J., and Ferrara, N. 1997. Differential transcriptional regulation of the two vascular endothelial growth factor receptor genes: Flt-1, but not Flk-1/ KDR, is upregulated by hypoxia. J. Biol. Chem. 272: 2365923667.

Giaccia, A.J. and Kastan, M.B. 1998. The complexity of p53 modulation: Emerging patterns from divergent signals. Genes \& Dev. 12: 2973-2983.

Gidday, J.M., Fitzgibbons, J.C., Shah, A.R., and Park, T.S. 1994. Neuroprotection from ischemic brain injury by hypoxic preconditioning in the neonatal rat. Neurosci. Lett. 168: 221224.

Gidday, J.M., Shah, A.R., Maceren, R.G., Wang, Q., Pelligrino, D.A., Holtzman, D.M., and Park, T.S. 1999. Nitric oxide mediates cerebral ischemic tolerance in a neonatal rat model of hypoxic preconditioning. I. Cereb. Blood Flow. Metab. 19: $331-340$

Giri, D. and Ittmann, M. 1999. Inactivation of the PTEN tumor suppressor gene is associated with increased angiogenesis in clinically localized prostate carcinoma. Hum. Pathol. 30: 419-424.

Gnarra, J.R., Tory, K., Weng, Y., Schmidt, L., Wei, M.H., Li, H., Latif, F., Liu, S., Chen, F., Duh, F.M., et al. 1994. Mutations of the VHL tumor suppressor gene in renal carcinoma. Nat. Genet. 7: 85-90.

Gothie, E., Richard, D.E., Berra, E., Pages, G., and Pouyssegur, J. 2000. Identification of alternative spliced variants of human hypoxia-inducible factor-1 $\alpha$. J. Biol. Chem. 275: 6922-6927.

Graeber, T.G., Osmanian, C., Jacks, T., Housman, D.E., Koch, C.J., Lowe, S.W., and Giaccia, A.J. 1996. Hypoxia-mediated selection of cells with diminished apoptotic potential in solid tumors. Nature 379: 88-91.

Greenlee, R.T. 2000. Cancer statistics. CA Cancer I. Clinicians 
50: 7-33.

Guo, Y., Jones, W.K., Xuan, Y.-T., Tang, X.-L., Bao, W., Wu, W.-J., Han, H., Laubach, V.E., Ping, P., Yang, Z., et al. 1999. The late phase of ischemic preconditioning is abrogated by targeted disruption of the inducible NO synthase gene. Proc. Natl. Acad. Sci. 96: 11507-11512.

Habib, G.B., Heibig, J., Forman, S.A., Brown, B.G., Roberts, R., Terrin, M.L., and Bolli, R. 1991. Influence of coronary collaterals on myocardial infarct size in humans: Results of phase I thrombolysis in myocardial infarction (TIMI) trial. Circulation 83: 739-746.

Haddad, J.J., Olver, R.E., and Land, S.C. 2000. Antioxidant/prooxidant equilibrium regulates HIF- $1 \alpha$ and NF- $\kappa B$ redox sensitivity: Evidence for inhibition by glutathione oxidation in alveolar epithelial cells. J. Biol. Chem. (in press).

Halterman, M.W., Miller, C.C, and Federoff, H.J. 1999. Hypoxia-inducible factor- $1 \alpha$ mediates hypoxia-induced delayed neuronal death that involves p53. J. Neurosci. 19: 6818-6824.

Herman, J.G., Latif, F., Weng, Y., Lerman, M.I., Zbar, B., Liu, S., Samid, D., Duan, D.S., Gnarra, J.R., Linehan, W.M., et al. 1994. Silencing of the VHL tumor suppressor gene by DNA methylation in renal carcinoma. Proc. Natl. Acad. Sci. 91: 9700-9704.

Holland, E.C., Hively, W.P., DePinho, R.A., and Varmus, H.E. 1998. A constitutively active epidermal growth factor receptor cooperates with disruption of $\mathrm{G}_{1}$ cell-cycle arrest pathways to induce glioma-like lesions in mice. Genes \& Dev. 12: 3675-3685.

Huang, L.E., Gu, J., Schau, M., and Bunn, H.F. 1998. Regulation of hypoxia-inducible factor $1 \alpha$ is mediated by an $\mathrm{O}_{2}$-dependent degradation domain via the ubiquitin-proteasome pathway. Proc. Natl. Acad. Sci. 95: 7987-7992.

Ishii, N., Maier, D., Merlo A., Tada, M., Sawamura, Y., Diserens, A.C., and Van Meir, E.G. 1999. Frequent co-alterations of TP53, p16/CDKN2A, p14 ${ }^{\mathrm{ARF}}$, PTEN tumor suppressor genes in human glioma cell lines. Brain Pathol. 9: 469-479.

Iyer, N.V., Kotch, L.E., Agani, F., Leung, S.W., Laughner, E., Wenger, R.H., Gassmann, M., Gearhart, J.D., Lawler, A.M., Yu, A.Y., et al. 1998. Cellular and developmental control of $\mathrm{O}_{2}$ homeostasis by hypoxia-inducible factor $1 \alpha$. Genes \& Dev. 12: 149-162.

Iyer, N.V., Leung, S.W., and Semenza, G.L. 1998. The human hypoxia-inducible factor $1 \alpha$ gene: HIF1A structure and evolutionary conservation. Genomics 52: 159-165.

Jiang, B.-H., Rue, E., Wang, G.L., Roe, R., and Semenza, G.L. 1996. Dimerization, DNA binding, and transactivation properties of hypoxia-inducible factor 1. J. Biol. Chem. 271: 17771-17778.

Jiang, B.-H., Agani, F., Passaniti, A., and Semenza, G.L. 1997a. V-SRC induces expression of hypoxia-inducible factor 1 (HIF-1) and transcription of genes encoding vascular endothelial growth factor and enolase 1: Involvement of HIF-1 in tumor progression. Cancer Res. 57: 5328-5335.

Jiang, B.-H., Zheng, J.Z., Leung, S.W., Roe, R., and Semenza, G.L. 1997b. Transactivation and inhibitory domains of hypoxia-inducible factor $1 \alpha$ : Modulation of transcriptional activity by oxygen tension. J. Biol. Chem. 272: 19253-19260.

Jung, F., Palmer, L.A., Zhou, N., and Johns, R.A. 2000. Hypoxic regulation of inducible nitric oxide synthase via hypoxia inducible factor-1 in cardiac myocytes. Circ. Res. 86: 319-325.

Kallio, P.J., Okamoto, K., O’Brien, S., Carrero, P., Makino, Y., Tanaka, H., and Poellinger, L. 1998. Signal transduction in hypoxic cells: Inducible nuclear localization and recruitment of the $\mathrm{CBP} / \mathrm{p} 300$ coactivator by the hypoxia-inducible factor-1 $\alpha$. EMBO J. 17: 6573-6586.

Kallio, P.J., Wilson, W.J., O’Brien, S., Makino, Y., and Poellinger,
L. 1999. Regulation of the hypoxia-inducible transcription factor $1 \alpha$ by the ubiquitin-proteasome pathway. I. Biol. Chem. 274: 6519-6525.

Kanno, H., Kondo, K., Ito, S., Yamamoto, I., Fujii, S., Torigoe, S., Sakai, N., Hosaka, M., Shuin, T., and Yao, M. 1994. Somatic mutations of the von Hippel-Lindau tumor suppressor gene in sporadic central nervous system hemangioblastomas. Cancer Res. 54: 4845-4847.

Kimura, H., Weisz, A., Kurashima, Y., Hashimoto, K., Ogura, T., D'Acquisto, F., Addeo, R., Makuuchi, M., and Esumi, H. 2000. Hypoxia response element of the human vascular endothelial growth factor gene mediates transcriptional regulation by nitric oxide: Control of hypoxia-inducible factor-1 activity by nitric oxide. Blood 95: 189-197.

Kotch, L.E., Iyer, N.V., Laughner, E., and Semenza, G.L. 1999. Defective vascularization of HIF-1 $\alpha$-null embryos is not associated with VEGF deficiency but with mesenchymal cell death. Dev. Biol. 209: 254-267.

Kozak, K.R., Abbott, B., and Hankinson, O. 1997. ARNT-deficient mice and placental differentiation. Dev. Biol. 191: 297305.

Lee, S.H., Wolf, P.L., Escudero, R., Deutsch, R., Jamieson, S.W., and Thistlethwaite, P.A. 2000. Early expression of angiogenesis factors in acute myocardial ischemia and infarction. $N$. Engl. J. Med. 342: 626-633.

Li, J., Post, M., Volk, R., Gao, Y., Li, M., Metais, C., Sato, K., Tsai, J., Aird, W., et al. 2000. PR39, a peptide regulator of angiogenesis. Nat. Med. 6: 49-55.

Lisztwan, J., Imbert, G., Wirbelauer, C., Gstaiger, M., and Krek, W. 1999. The von Hippel-Lindau tumor suppressor protein is a component of an E3 ubiquitin-protein ligase activity. Genes \& Dev. 13: 1822-1833.

Maltepe, E., Schmidt, J.V., Baunoch, D., Bradfield, C.A., and Simon, M.C. 1997. Abnormal angiogenesis and responses to glucose and oxygen deprivation in mice lacking the protein ARNT. Nature 386: 403-407.

Marti, H.J., Bernaudin, M., Bellail, A., Schoch, H., Euler, M., Petit, E., and Risau, W. 2000. Hypoxia-induced vascular endothelial growth factor expression precedes neovascularization after cerebral ischemia. Am. J. Pathol. 156: 965-976.

Martin, C., Yu, A.Y., Jiang, B.-H., Davis, L., Kimberly, D., Hohimer, A.R., and Semenza, G.L. 1998. Cardiac hypertrophy in chronically anemic sheep: Increased vascularization is associated with increased myocardial expression of vascular endothelial growth factor and hypoxia-inducible factor 1. Am. J. Obstet. Gynecol. 178: 527-534.

Maxwell, P.H., Dachs, G.U., Gleadle, J.M., Nicholls, L.G., Harris, A.L., Stratford, I.J., Hankinson, O., Pugh, C.W., and Ratcliffe, P.J. 1997. Hypoxia-inducible factor 1 modulates gene expression in solid tumors and influences both angiogenesis and tumor growth. Proc. Natl. Acad. Sci. 94: 8104-8109.

Maxwell, P.H., Wiesener, M.S., Chang, G.W., Clifford, S.C., Vaux, E.C., Cockman, M.E., Wykoff, C.C., Pugh, C.W., Maher, E.R., and Ratcliffe, P.J. 1999. The tumour suppressor protein VHL targets hypoxia-inducible factors for oxygendependent proteolysis. Nature 399: 271-275.

Mazure, N.M., Chen, E.Y., Laderoute, K.R., and Giaccia, A.J. 1997. Induction of vascular endothelial growth factor by hypoxia is modulated by a phosphatidylinositol 3-kinase/ Akt signaling pathway in Ha-ras-transformed cells through a hypoxia inducible factor-1 transcriptional element. Blood 90: 3322-3331.

McMenamin, M.E., Soung, P., Perera, S., Kaplan, I., Loda, M., and Sellers, W.R. 1999. Loss of PTEN expression in paraffinembedded primary prostate cancer correlates with high Gleason score and advanced stage. Cancer Res. 59: 4291- 
4296.

Minet, E., Arnould, T., Michel, G., Roland, D., Mottet, D., Raes, M., Remacle, J., and Michiels, C. 2000. ERK activation upon hypoxia: Involvement in HIF-1 activation. FEBS Lett. 484: 53-58.

Mukhopadhyay, C.K., Mazumder, B., and Fox, P.L. 2000. Role of hypoxia-inducible factor 1 in transcriptional activation of ceruloplasmin by iron deficiency. J. Biol. Chem. (in press).

Norwitz, E.R. and Repke, J.T. 2000. Preeclampsia prevention and management. J. Soc. Gynecol. Invest. 7: 21-36.

Ozaki, H., Yu, A.Y., Della, N., Ozaki, K., Luna, J.D., Yamada, H., Hackett, S.F., Okamoto, N., Zack, D.J., Semenza, G.L., and Campochiaro, P.A. 1999. Hypoxia-inducible factor $1 \alpha$ is increased in ischemic retina: Temporal and spatial correlation with VEGF expression. Invest. Ophthal. Vis. Sci. 40: 182-189.

Palmer, LA., Semenza, G.L., Stoler, M.H., and Johns, R.A. 1998. Hypoxia induces type II NOS gene expression in pulmonary artery endothelial cells via HIF-1. Am. J. Physiol. 274: L212L219.

Pierce, E.A., Avery, R.L., Foley, E.D., Aiello, L.P., and Smith, L.E. 1995. Vascular endothelial growth factor/vascular permeability factor expression in a mouse model of retinal neovascularization. Proc. Nat1. Acad. Sci. 92: 905-909.

Plate, K.H., Breier, G., Weich, H.A., and Risau, W. 1992. Vascular endothelial growth factor is a potential tumor angiogenesis factor in human gliomas in vivo. Nature 359: $845-$ 848.

Pugh, C.W., O'Rourke, J.F., Nagao, M., Gleadle, J.M., and Ratcliffe, P.J. 1997. Activation of hypoxia-inducible factor-1; definition of regulatory domains within the $\alpha$ subunit. I. Biol. Chem. 272: 11205-11214.

Rak, J., Mitsuhashi, Y., Sheehan, C., Tamir, A., Viloria-Petit, A., Filmus, J., Mansour, S.J., Ahn, N.G., and Kerbel, R.S. 2000. Oncogenes and tumor angiogenesis: Differential modes of vascular endothelial growth factor up-regulation in rastransformed epithelial cells and fibroblasts. Cancer Res. 60: 490-498.

Ravi, R., Mookerjee, B., Bhujwalla, Z.M., Sutter, C.H., Artemov, D., Zeng, Q., Dillehay, L.E., Madan, A., Semenza, G.L., and Bedi, A. 2000. Regulation of tumor angiogenesis by p53-induced degradation of hypoxia-inducible factor $1 \alpha$. Genes \& Dev. 14: 34-44.

Richard, D.E., Berra, E., Gothie, E., Roux, D., and Pouyssegur, J. 1999. p42/p44 mitogen-activated protein kinases phosphorylate hypoxia-inducible factor $1 \alpha(\mathrm{HIF}-1 \alpha)$ and enhance the transcriptional activity of HIF-1. J. Biol. Chem. 274: 3263132637.

Rivard, A., Fabre, J.-E., Silver, M., Chen, D., Murohara, T., Kearney, M., Magner, M., Asahara, T., and Isner, J. M. 1999. Agedependent impairment of angiogenesis. Circulation 99: 111120.

Rivard, A., Berthou-Soulie, L., Principe, N., Kearney, M., Curry, C., Branellec, D., Semenza, G.L., and Isner, J.M. 2000. Agedependent defect in VEGF expression is associated with reduced HIF-1 activity. J. Biol. Chem. (in press).

Rizvi, A., Tang, X.L., Qiu, Y., Xuan, Y.T., Takano, H., Jadoon, A.K., and Bolli, R. 1999. Increased protein synthesis is necessary for the development of late preconditioning against myocardial stunning. Am. J. Physiol. 277: H874-H884.

Roberts, J. M. 2000. Preeclampsia: What we know and what we do not know. Semin. Perinatol. 24: 24-28.

Ruscher, K., Isaev, N., Trendelenburg, G., Weih, M., Iurato, L., Meisel, A., and Dirnagl, U. 1998. Induction of hypoxia inducible factor 1 by oxygen glucose deprivation is attenuated by hypoxic preconditioning in rat cultured neurons. Neuro- sci. Lett. 254: 117-120.

Ryan, H.E., Lo, J., and Johnson, R.S. 1998. HIF-1 $\alpha$ is required for solid tumor formation and embryonic vascularization. EMBO J. 17: 3005-3015.

Sabia, P.J., Powers, E.R., Ragosta, M., Sarembock, I.J., Burwell, L.R., and Kaul, S. 1992. An association between collateral blood flow and myocardial viability in patients with recent myocardial infarction. N. Engl. J. Med. 327: 1825-1831.

Salceda, S. and Caro, J. 1997. Hypoxia-inducible factor $1 \alpha$ (HIF$1 \alpha)$ protein is rapidly degraded by the ubiquitin-proteasome system under normoxic conditions: Its stabilization by hypoxia depends upon redox-induced changes. J. Biol. Chem. 272: 22642-22647.

Schultz, A., Lavie, L., Hochberg, I., Beyar, R., Stone, T., Skorecki, K., Lavie, P., Roguin, A., and Levy, A.P. 1999. Interindividual heterogeneity in the hypoxic regulation of VEGF: Significance for the development of the coronary artery collateral circulation. Circulation 100: 547-552.

Semenza, G.L. 1999a. Perspectives on oxygen sensing. Cell 98: $281-284$.

. 1999b. Regulation of mammalian $\mathrm{O}_{2}$ homeostasis by hypoxia-inducible factor 1. Annu. Rev. Cell Dev. Biol. 15: $551-578$.

2000a. HIF-1: Mediator of physiological and pathophysiological responses to hypoxia. J. Appl. Physiol. 88: $1474-1480$.

- 2000b. Hypoxia, clonal selection, and the role of HIF-1 in tumor progression. Crit. Rev. Biochem. Mol. Biol. 35: 71103.

Shibata, T., Giaccia, A.J., and Brown, J.M. 2000. Development of a hypoxia-responsive vector for tumor-specific gene therapy. Gene Ther. 7: 493-498.

Shuin, T., Kondo, K., Torigoe, S., Kishida, T., Kubota, Y., Hosaka, M., Nagashima, Y., Kitamura, H., Latif, F., Zbar, B., et al. 1994. Frequent somatic mutations and loss of heterozygosity of the von Hippel-Lindau tumor suppressor gene in primary renal cell carcinomas. Cancer Res. 54: 2852-2855.

Shweiki, D., Itin, A., Soffer, D., and Keshet, E. 1992. Vascular endothelial growth factor induced by hypoxia may mediate hypoxia-initiated angiogenesis. Nature 359: 843-845.

Stein, I., Itin, A., Einat, P., Skaliter, R., Grossman, Z., and Keshet, E. 1998. Translation of vascular endothelial growth factor mRNA by internal ribosome entry: Implications for translation under hypoxia. Mol. Cell. Biol. 18: 3112-3119.

Sutter, C.H., Laughner, E., and Semenza, G.L. 2000. HIF-1 $\alpha$ protein expression is controlled by oxygen-regulated ubiquitination that is disrupted by deletions and missense mutations. Proc. Nat1. Acad. Sci. 97: 4748-4753.

Tazuke, S.I., Mazure, N.M., Sugawara, J., Carland, G., Faessen, G.H., Suen, L.-F., Irwin, J.C., Powell, D.R., Giaccia, A.J., and Giudice, L.C. 1998. Hypoxia stimulates insulin-like growth factor binding protein 1 (IGFBP-1) gene expression in HepG2 cells: A possible model for IGFBP-1 expression in fetal hypoxia. Proc. Natl. Acad. Sci. 95: 10188-10193.

Tian, H., Hammer, R.E., Matsumoto, A.M., Russell, D.W., and McKnight, S.L. 1998. The hypoxia-responsive transcription factor EPAS1 is essential for catecholamine homeostasis and protection against heart failure during embryonic development. Genes \& Dev. 12: 3320-3324.

Wang, G.L. and Semenza, G.L. 1993. Desferrioxamine induces erythropoietin gene expression and hypoxia-inducible factor 1 DNA-binding activity: Implications for models of hypoxia signal transduction. Blood 82: 3610-3615.

. 1995. Purification and characterization of hypoxia-inducible factor 1. J. Biol. Chem. 270: 1230-1237.

Wang, G.L., Jiang, B.-H., Rue, E.A., and Semenza, G.L. 1995. 
Hypoxia-inducible factor 1 is a basic-helix-loop-helix-PAS heterodimer regulated by cellular O2 tension. Proc. Natl. Acad. Sci. 92: 5510-5514.

Wenger, R.H. 2000. Mammalian oxygen sensing, signalling and gene regulation. J. Exp. Biol. 203: 1253-1263.

Wenger, R.H., Rolfs, A., Kvietikova, I., Spielmann, P., Zimmermann, D.R., and Gassmann, M. 1997. The mouse gene for hypoxia-inducible factor- $1 \alpha$ - genomic organization, expression and characterization of an alternative first exon and 5' flanking sequence. Eur. J. Biochem. 246: 155-165.

Yu, A.Y., Frid, M.G., Shimoda, L.A., Wiener, C.M., Stenmark, K., and Semenza, G.L. 1998. Temporal, spatial and oxygenregulated expression of hypoxia-inducible factor 1 in the lung. Am. J. Physiol. 275: L818-L826.

Yu, A.Y., Shimoda, L.A., Iyer, N.V., Huso, D.L., Sun, X., McWilliams, R., Beaty, T., Sham, J.S.K., Wiener, C.M., Sylvester, J.T., and Semenza, G.L. 1999. Impaired physiological responses to chronic hypoxia in mice partially deficient for hypoxia-inducible factor $1 \alpha$. J. Clin. Invest. 103: 691-696.

Zagzag, D., Zhong, H., Scalzitti, J.M., Laughner, E., Simons, J.W., and Semenza, G.L. 2000. Expression of hypoxia-inducible factor $1 \alpha$ in human brain tumors: Association with angiogenesis, invasion, and progression. Cancer 88: 2606-2618.

Zhong, H., De Marzo, A.M., Laughner, E., Lim, M., Hilton, D.A., Zagzag, D., Buechler, P., Isaacs, W.B., Semenza, G.L., and Simons, J.W. 1999. Overexpression of hypoxia-inducible factor $1 \alpha$ in common human cancers and their metastases. Cancer Res. 59: 5830-5835.

Zhong, H., Chiles, K., Feldser, D., Laughner, E., Hanrahan, C., Georgescu, M.-M., Simons, J.W., and Semenza, G.L. 2000. Modulation of HIF- $1 \alpha$ expression by the epidermal growth factor/ phosphatidylinositol 3-kinase/PTEN/AKT/FRAP pathway in human prostate cancer cells: implications for tumor angiogenesis and therapeutics. Cancer Res. 60: 1541-1545.

Zundel, W., Schindler, C., Haas-Kogan, D., Koong, A., Kaper, F., Chen, E., Gottschalk, A.R., Ryan, H.E., Johnson, R.S., Jefferson, A.B., et al. 2000. Loss of PTEN facilitates HIF-1-mediated gene expression. Genes \& Dev. 14: 391-396. 


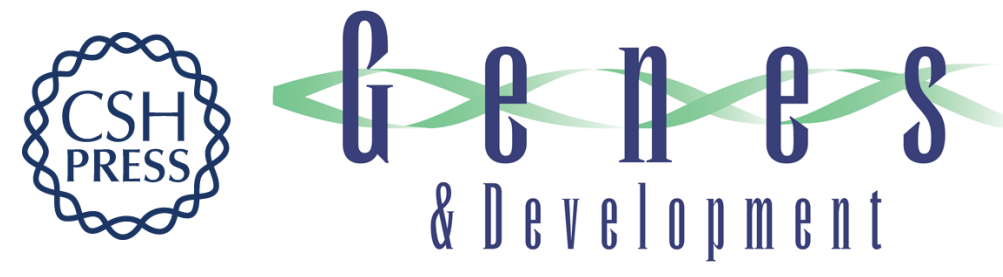

\section{HIF-1 and human disease: one highly involved factor}

Gregg L. Semenza

Genes Dev. 2000, 14:

Access the most recent version at doi:10.1101/gad.14.16.1983

References This article cites 99 articles, 50 of which can be accessed free at: http://genesdev.cshlp.org/content/14/16/1983.full.html\#ref-list-1

License

Email Alerting Receive free email alerts when new articles cite this article - sign up in the box at the top Service right corner of the article or click here.

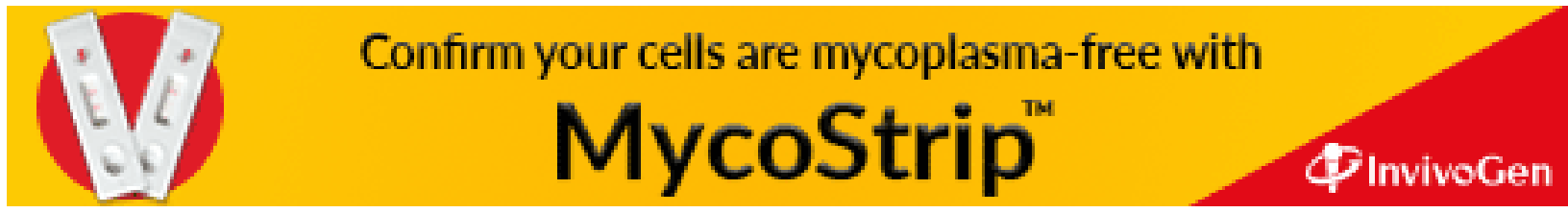

